Pacific Islands and Australasia shone as exemplars of media freedom, while several Asian countries, such as Burma, North Korea, China, Laos and Vietnam were rated poorly because of their state controls on the media.

Scandinavian countries took out the first five positions in the rankings of 194 nations. North Korea came in last.

While rated Free, Australia was criticised for its revitalisation of sedition laws and contempt charges against two Melbourne journalists and was ranked 31 on the international scale, well behind New Zealand at 10. Pacific Island nations categorised as Free included Palau (12) Marshall Islands (15), Micronesia (35), Vanuatu (52), Tuvalu (53), Fiji and Kiribati (59), Papua New Guinea and Samoa (65), and Nauru and the Solomon Islands (69).

Tonga was the worst performing Pacific island nation, ranked at 74 .

The survey serves a dual purpose in that it is an excellent research tool with its account of important media events in each country and a useful lobbying resource for advocates of media freedom in an individual country or in the broader region.-MARK PEARSON, professor of journalism at Bond University, Queensland

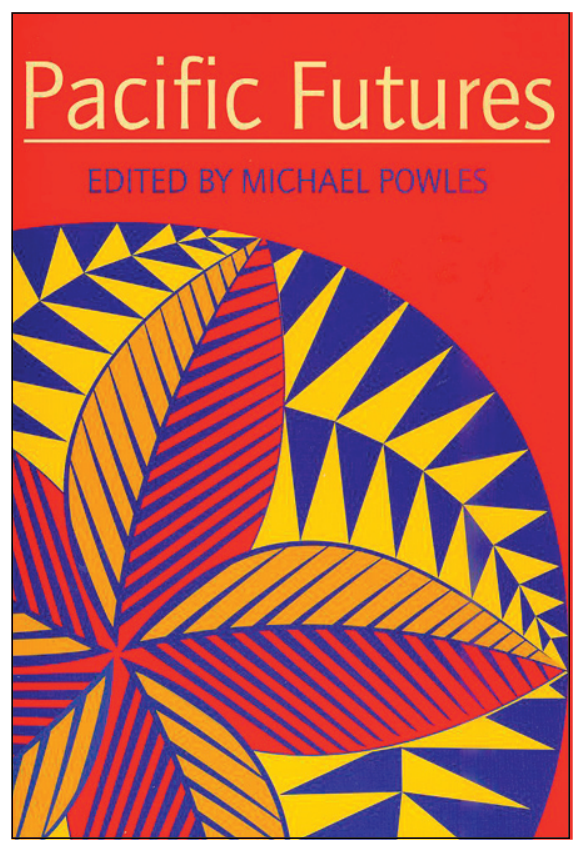

\section{Crucial democracy media role}

Pacific Futures, edited by Michael Powles. Wellington: Pacific Cooperation Foundation; Canberra: Pandanus Books, 2006. 260 pp. ISBN 1740761871.

$\begin{array}{lrr}\text { AmOAN } & \text { Prime } & \text { Minister } \\ \text { Tuila'epa } & \text { Sailele } & \text { Aiono }\end{array}$ Malielegaoi waxed eloquently about the future of the Pacific in the foreword to this handsome volume. Noting the vision adopted by Pacific leaders in Auckland in April 2004, he said they must offer Pacific solutions to the unique Pacific challenges. Quoting from the vision declaration, Tuilaepa 
said: 'We seek a Pacific region that is respected for the quality of its governance ... and for its defence and promotion of human rights' ( $p$. vii).

Yet many chapters in Pacific Futures examine the elusive and thorny nature of democracy and its weaknesses in the region, governance problems, the tension between human rights and culture, law reform and nation-building, neo-liberalism and the 'disciplining' of Pacific Island states, and 'whose Oceania'-contending visions of community.

One particularly illuminating chapter is 'Democracy and its prospects' (or lack of it) by Pacific programme director Dr Teresia Teaiwai at Victoria University and Dr Malakai Kolomatatangi of Canterbury University's National Centre for Research on Europe.

Tracing the evolution of postcolonial civic and popular cultures in the Pacific, the pair point out that the former, often elitist, have too narrow a base to support democracy while a mass culture is important in that it sometimes allows change from the bottom up. The authors examine developments in East Timor-currently facing its first presidential election since independence-and French Polynesia, for example, in an overview of the region.

Teaiwai and Kolomatatangi debunk the notion that colonial powers ought to be credited with introducing the concept of democracy and its formal political structures into the Pacific: 'Colonial rule, by definition, could not be democratic. At its best, colonial rule provided a limited form of political representation and participation; at its worst, it provided none' (p. 24).

The authors note the lack of ideological and policy depth to political party formation, the poor representation of women and the role of the media as 'crucial participants' in the development of democratic culture in the Pacific (p. 26).

Tongan migrants living abroad have challenged the political establishment in internet chat forums. But the concept of a free press has remained under constant attack.

Publishers Kalafi Moala of Taimi 'o Tonga and Sano Malifa of the Samoa Observer are granted special mention for their resistance to governments trying to 'limit or censor' media coverage.-Associate professor DAVID ROBIE, director, AUT University's Pacific Media Centre. 


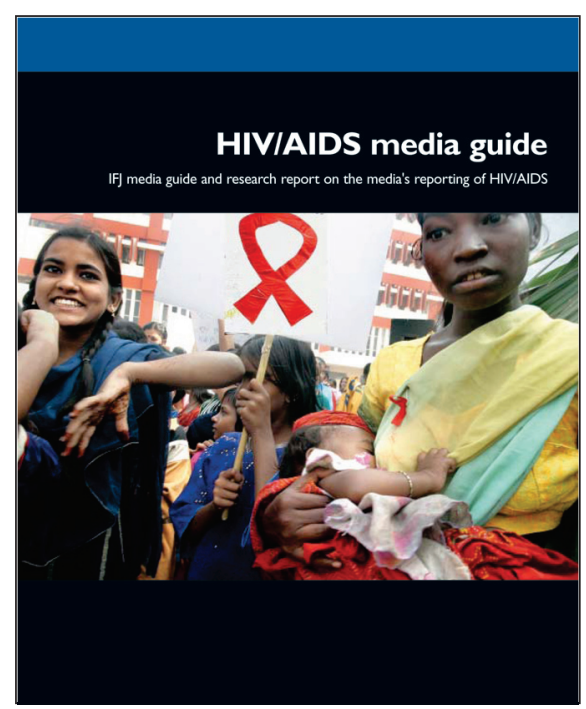

Reporting guide for a crisis

HIVIAIDS Media Guide and Research Report on the Media's Reporting of HIVIAIDS, by Ruth Polland and Emma Walters. Brussels: International Federation of Journalists, 2006. 27 pp. www.ifj-asia.org

T HE figures are difficult to grasp: 65 million have been infected with HIV and 25 million people have died since the disease was first detected in 1981. Currently, 38 million people are infected with the virus and this figure could double by 2020.

Closer to home, the National AIDS Council in Papua New Guinea (PNG) announced in May 2006 that there were at least 100,000 cases within the country and that PNG could experience a similar AIDS epidemic that has devastated several Southern African countries where infections rates account for more than 25 percent of some populations.

While the media have a significant role to play by informing the public and holding governments to account, a more immediate problem is how can journalists report effectively on a disease that has been around for more than 20 years, as is the case in PNG.

In light of this, the HIV/AIDS Media Guide is indeed a timely publication as it aims to improve the reporting of HIV worldwide.

The booklet, published by the International Federation of journalists (IFJ) and sponsored by the Swedish Trade Union movement, is divided into three parts: the basics, the media and more about HIV. It provides answers to frequently asked questions and presents explanations on transmission, treatments, opportunistic infections and alternative terms to use so as to avoid promoting misconceptions about people living with HIV and AIDS.

These sections are extremely useful, especially for their clarity and precision.

The section on research focused on six countries across Africa and Asia. The countries were: the 